УДК 616.89-008.442.6

doi: $10.15330 / p s .9 .1 .44-51$

\author{
Марія Клименко \\ Львівський національний університет імені Івана Франка \\ maria.klymenko@outlook.com
}

\title{
НАРЦИСИЧНА САМОРЕГУЛЯЦІЯ ОСОБИСТІСНОГО САМОЗДІЙСНЕННЯ
}

\begin{abstract}
Теоретично проаналізовано проблему функціонування наричисичної саморегуляиії особистості, ї̈ зв 'язку із особистісним самоздійсненням. Нариисична саморегуляція - механізм, який здатен ефективно підтримувати цілісність та зв'язок усіх елементів Self-системи, зберігати позитивне уявлення про себе. Виявлено, що самоцінність особистості грає роль індикатора саморегулятивних процесів, щуо мають стосунок до загальної осмисленої екзистениійної зміни особистості. Емпірично підтверджено, щуо нариисична саморегуляція яка вивчається у загальному контексті сили Self, перебуває у статистично значущому зв'язку із параметрами особистісного самоздійснення та задоволеності життям: чим більш адекватною є нариисична саморегуляція, тим ефективніме проявлясться персональність людини, ї̈ здатність до самотрансцендентності, свободи й особистісної відповідальності також ії екзистенційність. Адекватне функиіонування нарцисичної саморегуляції існує у прямому зв'язку із суб'єктивною оцінкою життя як більш осмисленого та наповненого індивідуальними життевими змістами та иуінностями. Досліджено, щзо такі особи більи схильні перебувати в діалогічному обміні зі світом і тим наблизитися не тільки до когнітивно вималюваного уявлення про ціннісні сенси, але $i$ до їх втілення, та є сприятливими до того, аби цінності впливали на їх особистісну структуру. Тож нарцисична саморегуляиія - ие механізм, який дбає про здорову самоиінність людини, їі иілісність, автентичне сприйняття себе у світі наповненому цінностями, на які і спрямовує свою психічну активність особа. Тобто адекватний, або іншими словами, «здоровий» нариисизм є необхідною ланкою в структурі Self-cамоцінність - самоздійснення.

Ключові слова: нариисична саморегуляція, система Self, самоздійснення, задоволеність життям, екзистенційність, самоцінність, сповненість.
\end{abstract}

Постановка проблеми та ії значення. В умовах культурних трансформацій, заснованих на принципах особистої ініціативи, ефективності, використання ресурсів задля утвердження власного як матеріального, так і психологічного благополуччя, все більш актуальним стає питання ролі здорового нарцисизму в щоденній життєтворчій активності людини, переживання iï буття як такого, що є осмисленим і скерованим на екзистенційні цінності. Індивідуалістична орієнтація сучасного суспільства зумовлює необхідність дослідження стратегій особистісного самоздійснення, актуалізація яких залежить від особливостей функціонування нарцисичної саморегуляції. Нарцисична саморегуляція відіграє роль одного з механізмів, що інтегрує та скеровує особистість у напрямку освоєння нових можливостей, нових форм почуттів, переживань, подій, думок, у визнанні себе та самовираженні, $\epsilon$ джерелом особистісної самоцінності. Питання зв'язку саморегуляції особливого психодинамічного типу та переживання людиною особистого самоздійснення дотепер залишається відкритим у сенсі як теоретичного обгрунтування, так і емпіричного вивчення.

Аналіз останніх досліджень проблеми. Існує велика кількість психологічних концепцій, що осмислюють проблему нарцисизму в межах психічної норми, проте неоднозначних. Проблема нарцисичної саморегуляції відображається у працях 3. Фройда, Х. Когута, О. Кернберга, Дж. Міллера, К. Морф, Д. Фостера й К. Кембела, Р. Раскіна. Звертаючись до «витоків» осмислення цього конструкту, варто зазначити, що й 3. Фройд теоретично обгрунтував поняття нарцисичної саморегуляції через ідею руху лібідо. Х. Кохут визначив нарцисичну саморегуляцію як механізм задоволення нормальних динамічних потреб Я. О. Кернберг аналізував нормальний нарцисизм дорослого як адаптивний спосіб саморегуляції, корекції та підтримання стабільної самооцінки і уявлень про себе. А К. Морф та Ф. Родвальт розуміють їі вже як систему персональних стратегій зв'язку особистості з певною ситуацією, що є стимульованою потребою досягнення цілей.

Проблема особистісного самоздійснення найбільш широко досліджувалася через вектор пошуку і реалізації сенсу життя, призначення людини, а більш конкретно - визначення 
життєвого смислу, його досягнення. В рамках екзистенційної психології питання актуалізувалось В. Франклом, С. Мадді, Р. Меєм, А. Ленгле, К. Орглер, І. Яломом (самоздійснення як самотрансцендеція й наявність сенсу життя, прямування до смислу), Д. Лєонтьєвим (смисложиттєві орієнтаціi)), Л. Коганом (стиль і смисл життя), Т. Титаренко (життєвий світ, «буття в світі», світ включає смисли), Б. Братусем (особистісне самоздійснення, орієнтоване на людську сутність). Проте досі немає єдиного визначення терміну самоздійснення й не розмежовано форми його прояву.

Мета статті полягає в теоретичному обгрунтуванні та емпіричному вивченні зв'язку функціонування нарцисичної саморегуляції та переживання людиною своєї самоздійсненності.

Методи та методики. Емпіричне дослідження здійснювалося задля з'ясування зв'язку функціонування нарцисичної саморегуляції та переживання людиною особистісного самоздійснення. Теоретичний же аналіз - це підгрунтя методологічної ідеї статті. Перш за все поставало завдання виявити, чи цей міжконструктний зв'язок взагалі можна зафіксувати та якими є його особливості. Обстежено 90 осіб віком від 18 до 21 року (юнацький вік та період ранньої дорослості) - 44 хлопці і 46 дівчат, що є студентами львівських вищих навчальних закладів. Методики дослідження: тест оцінки нарцисизму «Self» (Ф. Денеке та Б. Хільгеншток), «Шкала Екзистенції» (А. Ленгле), опитувальник «Задоволеність життям» (Е. Дінер). Дані, отримані у результаті дослідження групи, опрацьовані з допомогою програм Exel та Statistica 8.0. Використано такі методи статистичного аналізу: кластерний та кореляційний.

Виклад основного матеріалу дослідження. Саморегуляція - індивідуальний спосіб координації психічних процесів, станів, властивостей, компенсації дефіцитарних та оптимізації потенційних феноменів. Вона має дві форми прояву: усвідомлювана та несвідома. Усвідомлена саморегуляція - системно організований процес внутрішньої психічної активності людини в управлінні різними формами довільної активності. Несвідома ж саморегуляція - динамічно організований феномен, який діє у напрямках автоматичної регуляції процесів пізнання, емоцій, поведінки, самооцінки. Нарцисична саморегуляція - один із механізмів несвідомої регуляції, який за допомогою саморефлексії може бути вивченим [2].

Феномен нарцисичної саморегуляції найбільш детально розглядається в рамках психодинамічної теорії об'єктних стосунків. Здоровою формою нарцисизму $\epsilon$ нормальний нарцисизм дорослого - це адаптивний спосіб саморегуляції, пов'язаний зі стабільністю уявлень особистості про себе та константністю внутрішніх образів; характеризується здатністю індивіда до довготривалих міжособистісних взаємин, що спирається на інтегрованість структури Я [1]. Механізм формування «здорового нарцисизму» завершується інтерналізацією ідеалізованого Яоб'єкта в інтрапсихічну структуру, що породжує Его-ідеал та здатність Супер-Его до самостійної ідеалізації. Загалом система саморегуляції працює в напрямках: базового задоволення чуттєво-тілесних потреб, задоволення потреби у впевненості/безпеці та в стабільній самооцінці, в сенсі життя, освоєнні нових можливостей, самовираженні [2].

Нарцисична саморегуляції існує і діє у структурі всієї системи Self особистості. Selfсистема (або «само динамізм») - це сукупність переживань та досвіду людини, що використовуються нею в описі своєї самосвідомості. Цей конструкт був уведений в психодинамічну теорію С. Салліваном. На думку вченого, головним завдання Self-системи $є$ регулювання та зведення до мінімуму відчуття тривоги індивідом [7]. Загалом С. Салліван розглядав Self-систему як основну структуру в розвитку особистості, зародки якої починають з'являтися вже у шестимісячної дитини і далі формуються шляхом інтеграції «поганого» та «Хорошого мене»[7]. Нарцисична саморегуляція - один iз Self-механізмів, який підтримує в нормі цілісність та стабільність усієї Self-системи. Ї̈̈ функцією є інтегрування уявлень про себе в контексті здорової самоцінності.

Показником порушеного механізму функціонування нарцисичної системи регуляції $є$ нестабільне почуття власної цінності (як завищене, так і надмірно занижене), для підтримки 
якого психіка людини використовує компенсаторні механізми для захисту й збереження власної цілісності та цінності [6].

Нарцисична саморегуляція може здійснюватися в різних напрямках, зокрема виступає базою емоційно-оцінкових ставлень суб'єкта до себе, до різних сфер свого життя (визнання, самовираження), а за словами Х. Кохута, може бути джерелом «самоздійснення», прояву «здорових» рис: амбіцій, натхнення, ідеалів [1]. У контексті теоретичного та емпіричного дослідження цікавим є власне вивчення можливого зв'язку між функціонуванням такого типу психодинамічної саморегуляції та переживанням особистістю своєї самоздійсненності.

Поняття самоздійснення - багатогранне у своєму розумінні, оскільки охоплює розвиток особистості на різних життєвих етапах. Самоздійснення як «Self-fulfillment» введено К. Гольдштейном у 1940 році [5]. В україномовній літературі використовується еквівалентний термін «сповненість», який цілком відповідає значенню «Self-fulfillment». У найбільш поширеному розумінні самоздійснення - це те, що дозволяє людині реалізувати духовну компоненту свого внутрішньоособистісного змісту. Екзистенційне самоздійснення - це рух глибоко всередину власного Я, в глибину розуміння себе, своїх цінностей, осмислення життя, подолання протиріч людського існування. Багато авторів розташовують поняття самоздійснення поруч із самоактуалізацією та самореалізацією А. Маслоу та К. Роджерса. Та все ж самоздійснення - ширший і насичені ший феномен. Воно «існує» категоріями вибору, моральності особистості, духовного розвитку, аутентичного існування та єдності життєвих подій у розвитку Я [5].

Зрозуміло чому найбільш детально питання самоздійснення розкривається у контексті екзистенційно-аналітичної теорії особистості, зокрема в працях і практичній роботі австрійського психотерапевта й психолога А. Ленгле, який досліджує динаміку розвитку здорової особистості у зрілості, описує антропологічну суть нарцисизму та автентичності. Самоздійсненість у контексті теорії А. Ленгле - це радше стан, аніж процес, це не те, ким стає людина в результаті самореалізації, а віднайдена ідентичність [3]. Фундаментальними умовами екзистенції є мотивації, що лежать в основі всіх інших мотиваційних систем людини.

Розглянемо кожну з фундаментальних мотивацій:

1. Перша мотивація проявляє себе через питання: «Чи можу я бути в цьому світі?», що проявляє саму можливість існування у конкретній ситуації, «включеність» у життя. Наслідком прийняття життєвої ситуації стане довіра до світу.

2. Питання другої мотивації: «Чи подобається мені життя?», що виявляє здатність бути емоційно відкритим, свідчить про зародження почуттів та функції емоцій, про мистецтво насолоджуватися життям та глибоко страждати через втрату цінностей.

3. Питання третьої фундаментальної мотивації: «Чи маю я право бути таким як я є?» 3'ясовує механізм оцінювання, точніше - самооцінювання, що полягає в узгодженні ситуації та змісту їі цінностей з власним Я.

4. Четверта фундаментальна мотивація виявляє себе в запитанні: «Що я повинен робити?». Це рішучість утілити себе й свою суть, прагнення побачити й відчути включеність свого життя у систему більш загальних взаємозв'язків: суспільно-історичних, культурних, релігійних тощо [3].

Ключовим поняттям екзистенційної теорії самоздійснення є буття Person, або ж персональне буття (Personsein) - динамічний процес, що базується на подвійному співвідносенні із зовнішнім та внутрішнім. 3 одного боку, персональне буття існує в закритій формі особистісної інтимності, а з іншого - у відкритості й публічності зовнішнього світу. Завдання становлення Person - утвердити здорову внутрішню самоцінність через спілкування із зовнішнім світом [3].

Самоцінність - це феномени, що формуються протягом усього життя. Якщо б ці явища кристалізувалися до певної форми у процесі свого становлення, психологічна допомога й психотерапія не мали б ніякого сенсу. Визнання власної цінності відбувається через 
переживання важливості свого буття, критичну, проте адекватну оцінку. Наче існує внутрішня глибина у персональному існуванні, що ніколи не може бути вичерпаною до кінця.

Отже, виявлено та теоретично підтверджено, що нарцисична саморегуляція постійно має дотичність до процесів формування самоставлення, підтримання афективної рівноваги, позитивного уявлення про себе та особистісної цінності й цілісності. Самоцінність відіграє роль своєрідного індикатора ефективності регулятивних процесів. А висока адекватна самоцінність, яку потрібно кристалізувати внутрішньо й утвердити зовнішньо, - джерело переживання Я як цілісної та узгодженої структури психічних активностей, спрямованих на екзистенційну зміну.

Що ж відбуватиметься із Person, самоцінністю й здатністю до самоздійснення, якщо нарцисична саморегуляція функціонуватиме деструктивно? Оскільки Person - це основа екзистенційного переживання буття Self. Неефективність функціонування нарцисичної саморегуляції свідчить про нерозвиненість Self, бо власне у нормі розвинена самоцінність забезпечує таку Self-структуру, яка б могла здійснювати доступ до буття Person [4]. Тож проблема розвитку функцій Self може слугувати причиною нестійкості уявлень про себе.

\section{Емпіричне дослідження впливу нарцисичної саморегуляції на особистісне самоздійснення людини}

Для порівняння особливостей переживання самоздійсненності осіб із різним типом нарцисичної регуляції Self здійснено кластерний аналіз. За допомогою методу «Дерево кластеризації» виокремлено 3 блоки кластерів на основі методики «Self», що власне дає змогу вивчити особливості функціонування Self-системи особистості та своєрідності нарцисизму в цій саморегуляційній структурі.

За допомогою методу кластеризації «k-середніх» згруповано три відповідні кластери, в основу яких взято інтегративні показники Індексу функціонування системи Self та Нарцисизму. Тож у перший кластер увійшло 25 досліджуваних (28\% вибірки), у другий - 44 (49\% вибірки), у третій - 21 (23\% вибірки). Перший кластер - це група із досить високим рівнем нарцисизму та індексом функціонування Self дезадаптивним, другий кластер - група 3 показниками нарцисизму та індексу функціонування Self близькими до показників профілю ідеально сильної особистості, третій - сукупність осіб із зниженим рівнем нарцисизму та відчутною слабкістю Self.

Отже виокремлено один сукупний особистісний профіль із найбільш адекватно функціонуючою нарцисичною саморегуляцією та силою Self до показників ідеального Его. Натомість зафіксовано, що завищений нарцисизм, як i знижений, супроводжується порушеннями загальної діяльності організованої система світу людини, в центрі якого є іiі власна особистість, а окремі механізми Self-системи потерпають від впливів, що розбалансовують іï функціонування.

Оскільки перманентні процеси регуляції слідують двом важливим мотиваційним і діаметрально спрямованим принципам (одні спрямовані на досягнення вільного від напруги стану спокою-рівноваги, інші ж намагаються позбуватися такої рівноваги в пошуках сенсорноафективної стимуляції, нового досвіду та вражень, навіть якоїсь рушійної таємничості, тобто дотримуються принципу збудження), то ці процеси залишаються динамічно пов'язаними у стані повносило працюючої регуляції, а неадекватно функціонуюча нарцисична саморегуляція виявляється джерелом зрушень в організаційній та реорганізаційній діяльності Self, що може давати інформацію про ознаки надмірної рухливості або ж стагнаційної закостенілості регуляційних процесів. У такому разі нарцисичні зрушення можуть стимулювати виникнення психологічних проблем.

Внаслідок порівняння середніх показників трьох кластерів виявлено групу із найменш адекватно функціонуючим Self та нарцисичною саморегуляцією зокрема, найслабшим Self, найменшим базовим потенціалом надії, найбільш негативним тілесним образом себе, високою схильністю до соціальної ізоляції, прояву нарцисичного гніву, втрати контролю над емоціями та схильності до обезцінення. Особи цієї групи найбільше потребують використання захисних 
механізмів типу дереалізації-деперсоналізації, регресії до потреби архаїчного догляду, аби захистити Self від дестабілізаційних впливів та зберегти його крихку цілісність. Також виділено іншу групу (перший кластер) із такими особливостями як: найвищий рівень нарцисизму та порівняно більш адекватно функціонуюча Self-система, оскільки усі показники є дуже наближеними до тих, які зафіксовані у кластері другому (найбільш «здоровому»). Тобто саморегуляційна система має можливість підтримувати непатологічний рівень нарцисизму в його високому вимірі без глибинної шкоди Self.

Проаналізувавши кореляційні зв'язки у структурі першого кластера (завищений рівень нарцисизму та середня «сила» Self), виявлено, що показники особистісного самоздійснення перебувають у тісному зв'язку із силою Self людини. Слабкість Self існує в оберненому кореляційному (при $\mathrm{p}<0,01)$ зв'язку із показниками екзистенційності $(\mathrm{r}=-0,49)$ та сповненості $(\mathrm{r}=-0,59)$. А переживання свого Self як незначущого також негативно корелює 3 ними: екзистенційність ( $\mathrm{r}=-0,43)$ та сповненість $(\mathrm{r}=-0,55)$.

Дослідження кореляційних зв’язків у структурі другого кластера (група 3 показниками найбільш відповідними ідеальному профілю особистості) виявили, що екзистенційна наповненість, життєва сповненість, самотрансценденція, особистісна свобода та відповідальність, персональність корелюють із багатьма показниками, що оцінюють якість функціонування системи Self, проте зазначмо найважливіші: прямий зв'язок переживання екзистенційної наповненості особистості із нарцисизмом $(\mathrm{r}=0,42)$ та обернені взаємозв'язки із безсилим Self $(\mathrm{r}=-0,39)$, проявами деперсоналізації $(\mathrm{r}=-0,31)$, переживанням свого Self як незначного $(\mathrm{r}=-0,46)$, негативним тілесним образом Self $(\mathrm{r}=-0,34)$, прагненням захисту в архаїчному догляді $(\mathrm{r}=-0,30)$ та нарцисичною вигодою від хвороби ( $\mathrm{r}=-0,33)$; сповненість також перебуває у прямому зв'язку 3 проявами нарцисизму $(\mathrm{r}==0,45)$.

Отже, у виділеному в результаті статистичного аналізу кластері, що за своїми показниками $\epsilon$ найближчим профілю ідеально сильної особистості, сформувався прямий кореляційний зв'язок нарцисизму зі здатністю до самодистанціювання та самотрансценденції, свободою та відповідальністю, персональністю, екзистенційністю та сповненістю (Таблиця 1).

Прямі кореляційні зв'язки функціонування нарцисичної саморегуляції
із показниками особистісного самоздійснення у другому кластері
\begin{tabular}{|l|l|}
\hline & $\begin{array}{l}\text { Нарцисизм } \\
\text { при } p<0,01, r=\end{array}$ \\
\hline Екзистенційність & 0,42 \\
\hline Сповненість & 0,45 \\
\hline Персональність & 0,41 \\
\hline Самотрансценденція & 0,45 \\
\hline Свобода & 0,47 \\
\hline Відповідальність & 0,33 \\
\hline
\end{tabular}

Таблиия 1

Тобто адекватний, або іншими словами, «здоровий» нарцисизм чітко пов'язаний із вищими показниками екзистенційного самоздійснення особистості. Такі особи більше схильні перебувати в діалогічному обміні зі світом і завдяки цьому наблизитися до втілення своїх сутнісних сенсів, володіють більшою здатністю сприймати ціннісні «основи світу» й інтерналізувати їх у власну особистісну структуру, впевненіше крокують до ухвалення життєвих рішень, втілення в життя власних задумів, менше страждають від сумнівів, невпевненості, а навпаки - живуть з відчуттям, що «все робиться правильно» і відповідально. Можна зробити припущення, що висока та адекватна самоцінність - джерело переживання Я як цілісної та узгодженої структури психічних активностей, спрямованих на екзистенційну зміну. 
Дослідження кореляційних зв'язків у структурі третього кластера (група з показниками найнижчого рівня нарцисизму та найменш конструктивно функціонуючою системою Self) виявили: що гірше функціонує нарцисична саморегуляція (парціальні показники функціонування Self $є$ низькими), то гіршим $є$ переживання людиною себе особистістю, яка самоздійснюється. Зокрема страждає задоволеність життям, більшою є соціальна ізольованість $(\mathrm{r}=-0,48)$, низькою $\epsilon$ задоволеність тілом $(\mathrm{r}=-0,64)$, світ особистісних цінностей $\epsilon$ також досить мізерним $(\mathrm{r}=-0,36)$ (Таблиця 2).

Таблиця 2

Кореляційний зв'язок показників самоздійснення із показниками сили Self у третьому кластері

\begin{tabular}{|l|l|l|}
\hline & $\begin{array}{l}\text { Екзистенційність } \\
\text { при } p<0,01, r=\end{array}$ & $\begin{array}{l}\text { Сповненість } \\
\text { при } p<0,01, r=\end{array}$ \\
\hline Незначущість Self & $-0,32$ & $-0,33$ \\
\hline Обезцінювання об'єктів & $-0,48$ & $-0,51$ \\
\hline Ідеал самодостатності & 0,30 & 0,37 \\
\hline Іпохондричний захист від тривоги & 0,36 & 0,41 \\
\hline Нарцисична вигода від хвороби & 0,37 & 0,40 \\
\hline
\end{tabular}

Оскільки третій кластер показав найвищий рівень індексу функціонування системи Self iз його найзначнішою відмінністю від профілю ідеально сильної особистості, то надзвичайно важливим $€$ викристалізуваний зв'язок цього інтегративного показника 3 особливостями сповненості людини. Тобто що слабшою є система Self, то меншою є задоволеність життям, здатність до самотрансцендендування, страждає відчуття екзистенційної свободи. Тож можливість орієнтуватися в цьому світі, ухвалювати рішення, відповідати за їхнє втілення у життя, здатність до прояву власної сутності, здорова самоцінність уже не мають повноцінної та адекватної можливості бути розвиненими й пережитими в індивідуальному бутті.

Цікавим також є те, що виявлені як окремі виміри екзистенційності й сповненості у цьому кластері страждають, наче від певних «викривлень» самотрансцендендування та самодистанціювання. Створення внутрішньої дистанції, об'єктність, здатність знаходити у своєму існуванні цінності й відчувати їх емоційно справляють враження штучно допасованих. «Слабке» Self не має змоги впоратись із «сильними» вимогами усвідомлюваної саморегуляції, i Ахіллесова п'ята тут - зовнішня емоційна неконтрольованість в моменти психологічного напруження. Те, що мало б давати внутрішнє звільнення від полону афектів, упереджень i бажань, аби в них не заплутуватися, є крихким та непевним. Самотрансценденція в такому варіанті мовить про фрагментацію Я: розщеплення його на Self-психічне та Self-тілесне, покладаючи відповідальність за життєві невдачі насамперед на тілесне представництво. Цей параметр саморегуляції еквівалентний спробі уникнути тотального спустошення (навіть гіпотетичного) й знецінення особистості шляхом обмеження переживання власної малоцінності, що могла б становити загрозу для всього Self, i замінивши іï лише тілесним образом, таким чином ці загрози можна вдало дисоціювати, «відщепити».

Висновки. Нарцисична саморегуляція - механізм, здатний ефективно підтримувати цілісність та зв'язок усіх елементів структури Я, зберігати позитивне уявлення людини про себе, забезпечити адекватну та здорову любов до себе, почуття особистої значущості.

Самоздійснення - це поступальних рух особистості у напрямку розкриття власних здібностей, можливостей, ресурсів, спираючись на які, можна зробити життя більш продуктивним, конструктивним i, як наслідок, переживати його повноту та смисложиттєву наповненість. Власне розвиток самоцінності - це можливість прожити своє буття автентично і в гармонії 3 собою. Висока самоцінність, що робить Self сильним, - це джерело самоздійснення, доступу до духовного виміру особистості, до Person. 
Проблема самоцінності у вимірі здорового та патологічного нарцисизму є ключовою, оскільки $є$ зв'язною ланкою психодинаміки Self та здатності людини до глибокого й автентичного переживання життя. Тож вагомим завданням нарцисичної саморегуляції $\epsilon$ піклування про збереження здорового почуття власної цінності та самоповаги. Виявлено, що нарцисична саморегуляція, що вивчається у загальному контексті сили Self, перебуває у статистично значущому зв'язку з параметрами особистісного самоздійснення та задоволеності життям: що більш адекватною є нарцисична саморегуляція, то ефективніше проявляється

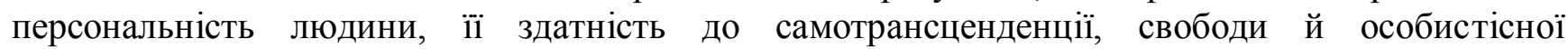
відповідальності, а також іiі екзистенційність, іншими словами - «включеність» у життя переживається повніше, існування суб' єктивно оцінюється як більш наповнене та осмислене.

Перспективою подалыших досліджень є 3'ясування причинно-наслідкового зв'язку (виокремлення чинників) між нарцисичною саморегуляцією та самоздійсненням, що підтверджуватиме або спростовуватиме вибудувану теоретичну концепцію. Така робота може бути використана як наукова база для досліджень якості життя осіб з різними профілями нарцисичної саморегуляції, його наповненості психологічними ресурсами, визначення стратегій психологічного супроводу особистісного зростання.

1. Кохут, Х. (2003). Анализ самости. Системный подход к лечению нарииссических нарушений личности. М.: Когито-Центр.

2. Клименко, М. Р. (2017). Особливості саморегуляції «здорового» нарцисизму. Проблеми сучасної психології, 37, 142-155.

3. Лэнгле, А. (2004). Введение в экзистенциально-аналитическую теорию эмоций: прикосновение к ценности. Вопросы психологии, 4, 3-21.

4. Лэнгле, А. (2002). Грандиозное одиночество. Нарциссизм как атропологически экзистенциальный феномен. Московский психотерапевтический журнал, 2, 34-58.

5. Gewirth, A. (1998). Self-Fulfillment. Princeton University Press, 6-12.

6. Morf, C., Rhodewalt, F. (2001). Unraveling the Paradoxes of Narcissism: A Dynamic Self-Regulatory Processing Mode. Psychological Inquiry, 12, 177-196.

7. Sullivan, H. S. (1953). The Interpersonal Theory of Psychiatry. Beginnings of the self-system. W. W. Norton \& Company, 158-170.

\section{REFERENCES}

1. Kohut, X. (2003). Analiz samosti. Sistemnyiy podhod k lecheniyu nartsissicheskih narusheniy lichnosti [Analysis of the selfidentity. A systematic approach to the treatment of narcissistic personality disorders]. M.: KogitoTsentr. (rus).

2. Klymenko, M. R. (2017). Osoblyvosti samorehuliatsii «zdorovoho» nartsysyzmu [The special characteristics of self-regulation of «healthy» narcisism]. Problemy suchasnoi psykholohii [Problems with Psychology], 37, 142-155. (ukr).

3. Lengle, A. (2004). Vvedenie v ekzistentsialno-analiticheskuyu teoriyu emotsiy: prikosnovenie k tsennosti [Introduction to Existential-Analytical Theory of Emotions: touching value]. Voprosyi psihologii [Psychology issues], 4, 3-21. (rus).

4. Lengle, A. (2002). Grandioznoe odinochestvo. Nartsissizm kak atropologi- cheski-ekzistentsialnyiy fenomen [Great loneliness. Narcissism as an atropologically existential phenomenon]. Moskovskiy psihoterapevticheskiy zhurna [Moscow Psychotherapeutic Journal], 2, 34-58. (rus).

8. Gewirth, A.(1998). Self-Fulfillment. Princeton University Press, 6-12.

5. Morf, C., Rhodewalt, F. (2001). Unraveling the Paradoxes of Narcissism: A Dynamic Self-Regulatory Processing Mode. Psychological Inquiry, 12, 177-196.

6. Sullivan, H. S. (1953). The Interpersonal Theory of Psychiatry. Beginnings of the self-system. W.W. Norton \& Company, 158-170.

\section{Maria Klymenko \\ NARCISSISTIC SELF-REGULATION OF THE PERSONAL FULFILLMENT}


The problem of functioning of personal narcissistic self-regulation and its connection with personal sense of selffulfillment was theoretically analyzed. Narcissistic self-regulation is a mechanism that can effectively maintain the integrity and stable connection between all elements of the Self-system, it also works on the maintaining a positive perception of Self. It was disclosed that the sense of the individual self-value plays the role of indicator (some kind of informer) for selfregulatory processes. The last ones are related to the general meaning of the existential change. It was empirically confirmed that narcissistic self-regulation, which was investigated as the general manifestation of Self's power, stays in statistically significant relations to subscales of the personal self-fulfillment and life satisfaction indicators: the more adequate the narcissistic self-regulation is - the more effective is the disclosure of human's personality, the ability to selftranscend and experience freedom, such people are more able to take responsibility on their «being» and «living». Also, the normal functioning of the narcissistic self-regulation exists in the straight connection with the subjective assessment of life as more meaningful and filled with individual vital senses and values. Such persons are able to stay in a dialogical exchange with the world and feel more naturally to tolerate life values that may influence on their personal Self structure. Thus, narcissistic self-regulation is a mechanism that takes care about the normal and healthy individual self-value and self-esteem, acts like the instrument of the integrity and the authentic perception of selfhoods and personal essence in the environment.

Keywords: narcissistic self-regulation, Self-system, self-fulfillment, well-being, existentiality, self-value. 